\title{
Examining the adaptability of collaborative governance associated with publicly managed ecosystems over time: insights from the Front Range Roundtable, Colorado, USA
}

\author{
Antony S. Cheng ${ }^{1}$, Andrea K. Gerlak ${ }^{2}$, Lisa Dale $^{3}$ and $\underline{\text { Katherine Mattor }}^{1}$
}

\begin{abstract}
We examine the adaptability of collaborative governance regimes associated with publicly managed ecosystems as they move from direction-setting to implementation phases. This is an under-researched topic and is particularly relevant given the growth of collaborative environmental governance efforts around the globe. Through an in-depth analysis of a case study spanning 10 years of the Front Range Roundtable in Colorado, USA, we examine the effect of forces internal and external to the Roundtable on three attributes associated with the adaptive capacity of environmental governance: social capital, learning, and flexibility in implementing innovative actions. We find that the Roundtable has been highly sensitive to internal and external changes, and that the absence of mechanisms through which social networks and learning can be durably linked to implementation decisions of bureaucracies with management authority compromises the Roundtable's continued adaptability. From this case study, we develop three empirically testable propositions related to social capital and learning, national policy change, and boundary objects as collaborative regimes transition to implementation, along with an analytical framework to examine collaborative governance change and adaptability over time.
\end{abstract}

Key Words: adaptive governance; boundary objects; collaborative governance; ecosystem management

\section{INTRODUCTION}

Collaborative governance of common-pool ecosystems and resources is expanding globally and is widely seen as contributing to the adaptive capacity of social-ecological systems (Armitage 2005, Folke et al. 2005, Lebel et al. 2006). Empirical research across ecosystem management contexts demonstrates how collaborative approaches can help in managing conflicts, building trust, pooling resources, building capacity, and sustaining action; collaboration is also shown to spark innovation, risk-taking, and more flexible, responsive actions because of the multiple viewpoints and resources that are leveraged through the collaborative process (Daniels and Walker 1996, Bernard and Young 1997, Cestero 1999, Wondolleck and Yaffee 2000, Bryan 2004, Sturtevant et al. 2005, Weber et al. 2005, Cheng and Sturtevant 2012, Gerlak et al. 2013).

Far less is known about the adaptability of collaborative governance regimes (CGRs) over time (Emerson et al. 2012, Emerson and Gerlak 2014; Imperial and Koontz, unpublished manuscript: http://people.uncw.edu/imperialm/Instructor/Papers/ APPAM 07 Imperial Koontz Final 115 07.pdf), especially as they move from direction-setting to implementation phases. Direction-setting occurs when stakeholders identify a shared sense of purpose, jointly produce and examine relevant data, and establish goals, operating ground rules, and possibly organize into sub-groups to examine issues in depth (Selin and Chevez 1995). Implementation generally refers to the actions taken by public and private entities at multiple levels of authority directed at attaining policy objectives (Van Meter and Horn 1975, DeLeon and DeLeon 2002), and includes the strategic mobilization and application of human, financial, and technological resources to alter routines (Montjoy and O'Toole 1979). Generally, the influence of CGRs on determining implementation actions and achieving measurable outcomes is unclear (Kenney 2001, Koontz 2005, Koontz and Thomas 2006, Margerum 2011). Some research speaks to internal group factors shaping implementation, such as having clearly defined goals, strong commitment of participants to the collaborative process and agreements, and institutional rules and arrangements facilitating coordination (Ansell and Gash 2008, Thomson et al. 2009, Emerson et al. 2012).

Others suggest that forces external to the CGR may influence implementation (Margerum 2007, Wyborn and Bixler 2013). In the case of CALFED, a collaboration among 25 state and federal agencies to address water supply and ecological health issues of the San Francisco Bay and Sacramento-San Joaquin River Delta, and considered to be one of the most ambitious experiments in collaborative environmental policy in the United States, researchers suggest that implementation failed for a number of reasons. These reason were both internal and external to the collaborative regime, such as a lack of leadership, differences in culture and goals of actors, and fundamental oppositions of interests (Bobker 2009, Hanemann and Dyckman 2009, Kallis et al. 2009, Taylor and Short 2009).

Here, we seek to shed light on the adaptability of collaborative governance associated with publicly managed ecosystems (e.g., national forests) over time as the focus shifts from directionsetting to implementation. Collaborative governance of publicly managed resources is challenging because central government bureaucracies still maintain ownership control and decisionmaking authority, even as these systems are increasingly moving toward multi-stakeholder and community-based collaborative governance (Western et al. 1994, Wondolleck and Yaffee 2000, White and Martin 2002, Edmunds and Wollenberg 2004, Cheng 2006, Elbakidze et al. 2010). We examine the adaptability of collaborative governance through an in-depth case study analysis of the Front Range Roundtable ("Roundtable") in Colorado, USA. We used a grounded theory approach to analyzing our data to generate three themes of adaptability. Following Eisenhardt 
(1989), our objective is to initiate the development of empirically testable propositions and analytical frameworks. Such frameworks are in short supply (Emerson et al. 2012; Imperial and Koontz, unpublished manuscript: http://people.uncw.edu/ imperialm/Instructor/Papers/APPAM 07 Imperial Koontz Final_11_5 07.pdf) and are particularly relevant because multistakeholder collaborative governance approaches are increasing in the context of publicly managed ecosystems.

\section{LITERATURE REVIEW}

Insights for understanding and examining the adaptability of CGRs can be found across literature on adaptive governance, comanagement, collaboration, and organizational theory. In our review of the literature, three attributes associated with adaptive institutions stand out: social capital, learning, and flexibility. For each attribute, we developed questions that guided our grounded theory inquiry.

Social capital is broadly defined as the networks of social relationships that foster trust through reciprocal behavior (Pelling and High 2005). Pelling and High (2005) contend that social capital can be mobilized as a resource to mitigate risk, in their case, vulnerabilities associated with climate change. Although some studies show that social capital is vital to the performance of CGRs and, in turn, CGRs are themselves enablers of social capital (Sturtevant et al. 2005, Wagner and Fernandez-Gimenez 2009), other studies suggest that social capital can be overwhelmed by forces internal and external to a CGR, leading to diminished progress or even failure (Singleton 2002, Walker and Hurley 2004, Bonnell and Koontz 2007). As CGRs move into implementation of programs and projects for publicly managed ecosystems, to what extent does social capital overcome internal and external forces and influence desired structural and decisionmaking changes?

Learning is a cornerstone of social adaptive capacity and collaborative adaptive governance of natural resources (Maarleveld and Dabgbégnon 1999, Buck et al. 2001, Bouwen and Taillieu 2004, Keen et al. 2005, Fernandez-Gimenez et al. 2008, Berkes 2009). Structures and processes that allow a collective governance body to co-produce different forms of knowledge of a natural resource system and foster robust learning about trends, cause-and-effect relationships, and feedbacks can result in actions to reduce risks and vulnerabilities from rapid changes (Folke et al. 2005). Social learning can be seen as a process whereby: (1) a change in understanding has taken place in the individuals involved, (2) this change goes beyond the individual and becomes situated within wider social units or communities of practice, and (3) the change occurs through social interactions and processes between actors within a social network (Reed et al. 2010).

Other scholars call attention to how different types of learning influence implementation or nonimplementation in environmental co-management contexts (Munaretto and Huitema 2012), or to characteristics of the collective setting that shape learning (Gerlak and Heikkila 2011, Heikkila and Gerlak 2013). In particular, these studies suggest that for learning to translate into implementation actions, certain attributes of institutional structure, social interactions, and technological resources and tools must be in place to absorb learning. What are these attributes and to what extent do they induce government actors with authority to implement programs and projects on publicly managed ecosystems to absorb and act on learning?

Finally, the ability of a CGR to implement flexible, innovative actions signifies a high degree of adaptability. Gupta et al. (2010) propose that institutions that allow room for autonomous change are ones that provide continuous access to information, the ability to act according to plan, and the capacity to improvise. However, the organizational literature tells us that government bureaucracies are notoriously resistant to change (Weeks and Whimster 1985, Burke 2002). Even when social capital and learning are fostered through collaborative processes, organizational actors may still find themselves operating under organizational routines and standard operating procedures (Agranoff 2006). What are the pathways and mechanisms that allow the social capital and learning that occurs in CGRs to manifest in changes in the implementation actions? We view these attributes and questions as "sensitizing concepts" (Bowen 2006) that helped to guide our inquiry rather than as hypotheses to be tested empirically.

\section{CASE STUDY CONTEXT: THE COLORADO FRONT RANGE ROUNDTABLE}

Our case study focuses on collaborative efforts by a diverse range of stakeholders to advance ecological restoration and wildfire risk reduction in Colorado's Front Range national forest lands. This geography is where the Great Plains rise into the foothills of the Colorado Rocky Mountains (Fig. 1). More than 4 million people live in this region. Two national forests managed by the U.S. Forest Service ("Forest Service") comprise a major focus for forest restoration in Colorado's Front Range, the Arapaho-Roosevelt and Pike-San Isabel National Forests.

Fig. 1. Vicinity map of the Front Range Roundtable geographic area, encompassing 10 counties in Colorado, USA.

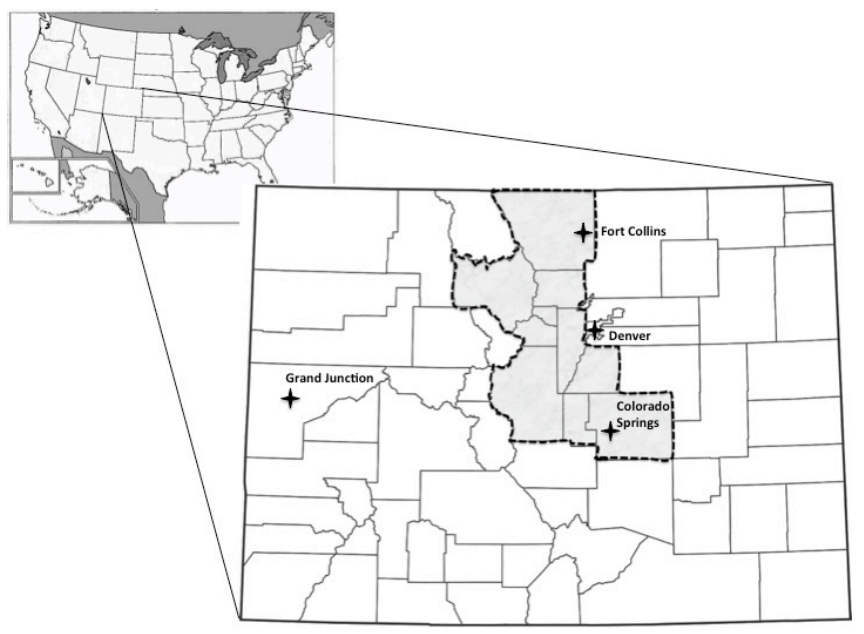

The Roundtable had its genesis in a crisis event: the Hayman Fire in June 2002, which burned nearly 55,870 ha of Ponderosa pine forest southwest of the Denver metropolitan area. In combination with other wildfires in Colorado's Front Range in 2000-2002, the Hayman Fire highlighted the high degree of vulnerability of Colorado's Front Range Ponderosa pine forests and human 
communities to large and severe wildfires. In response to the Hayman Fire, as well as to new national-level wildfire management policies resulting from the 2000 and 2002 wildfire seasons, a broad range of governmental and nongovernmental organizations self-organized to develop and implement forest management strategies to reduce wildfire risk and restore forest conditions that likely existed prior to the intensive Euro-American settlement in the late 1800 's that disrupted natural fire regimes. Participants included federal, state, and county government agencies; environmental organizations; academic and scientific researchers; and user groups and trade associations (Table 1). This broader network became known as the Front Range Roundtable.

Table 1. Types and numbers of organizations participating in the Front Range Roundtable, 2006.

\begin{tabular}{lc}
\hline \hline Type of organization & Number of organizations \\
\hline Federal government agencies & 9 \\
State government agencies & 7 \\
County and municipal & 10 \\
governments & 5 \\
Environmental organizations & 3 \\
Academic/scientific & \\
organizations & 10 \\
User groups and associations & \\
\hline
\end{tabular}

After the initial meetings to convene the Roundtable, participants organized around four working groups to focus their interests and energy on the following topics: community engagement, ecology, economics, and policy. Two paid positions were created: a facilitator to organize and lead the meetings, and a private consultant to coordinate the working groups and help with the organization of information. The first year of the Roundtable was spent developing a mission statement, vision, and roadmap. With these formative documents written, the ecology working group, comprising university and government scientists and government agency technical specialists, convened a series of meetings in 2004-2005 to identify $>162,000$ ha where treatments would simultaneously reduce hazardous fuels and restore forest health in Ponderosa pine-dominated landscapes. Data were assembled from multiple organizations, and provisional results were communicated between working participants and their parent organizations. The ecological information was passed on to the economics working group to determine what could realistically be accomplished and how it would be funded. Based on both working groups' results, the Roundtable developed and refined a set of recommended initiatives to be undertaken by federal, state, and local governments and private landowners. The final report, Living with Fire: Protecting Communities, Restoring Forests (FRFTP Roundtable 2006), was released and endorsed by the Colorado Governor in 2006, and was subsequently widely distributed and marketed by the community engagement and policy working groups to cultivate political and financial support for implementation.

Implementation of Roundtable recommendations was handed off to the government agencies with the necessary authority and resources to carry out forest restoration and fuel reduction projects. The expectation was that regular reporting of planned treatments and monitoring results would occur. In turn, the Roundtable would evaluate results and recommend changes as deemed necessary. However, Roundtable recommendations were overly broad, lacking specific direction as to where and how forest restoration was to occur. Additionally, the relationship between the Roundtable and implementing agencies was left undefined. It is at this stage, where the Roundtable shifted from directionsetting to implementation, that our case study embarks.

\section{METHODOLOGICAL APPROACH}

This transition between the Roundtable's direction-setting and implementation phases provides an exemplary case study for exploring the adaptability of a CGR in the context of publicly managed ecosystems and marks the starting point of our analysis. The adaptability attributes of social capital, learning, and flexibility helped to frame our inquiry as sensitizing concepts (Bowen 2006), as we did not hypothesize a priori how they interacted or influenced the Roundtable's transition to implementation. Instead, we pursued a grounded theory approach using qualitative research methods (Glaser and Strauss 1967, Corbin and Strauss 1990, Walker and Myrick 2006). In this vein, we used an iterative, inductive approach to construct general themes and patterns from our data (Charmaz 2006, Mills et al. 2006) concerning the Roundtable's adaptability; in turn, the grounded theory approach generated propositions for future research on the adaptability of CGRs in publicly managed ecosystems in general.

Four primary sources of data were gathered. First, in-depth semiinterviews with Roundtable stakeholders were conducted in autumn $2008(N=14)$ and autumn $2012(N=15)$. Interviews were strategically solicited from Roundtable members who had participated in at least $50 \%$ of Roundtable meetings since its inception and were identified as primary leaders in Roundtable affairs. The criterion of primary leadership was subjectively identified by interview subjects themselves, leading to a network sampling of interview subjects (Scott and Carrington 2011). Interview subjects in both time periods were asked to assess the Roundtable's organizational structure and composition, the effectiveness of the collaborative process, communication and interaction between stakeholders, implementation of goals, and resource availability and needs. The interview script provided sufficient latitude to allow subjects to define starting points, trajectories, and issues.

A second source of data was summaries of 18 interviews conducted by the Roundtable facilitator in summer 2009 as part of an effort to reorganize and revitalize the Roundtable as it struggled to transition beyond goal-setting into implementation. The facilitator's interviews focused on: perceived benefits of Roundtable actions to the participant's home organization, effectiveness of Roundtable strategies, effectiveness of Roundtable organizational structure and collaboration process, and linkages of the Roundtable to other partnerships and implementing agencies. Given the similarities in interview topics, we included the summaries in our analysis. Although we were not provided with the original interview texts, we had access to the facilitator's thematic summaries.

Third, we compiled and analyzed $>500$ pages of Roundtable meeting notes and reports published between 2004 and 2013. The documents provide a mechanism by which to trace the process by 
which the Roundtable organized and developed governance strategies, developed a shared knowledge foundation, defined goals, and coordinated action.

Finally, we relied on extensive participant observation: One of the authors participated in Roundtable meetings from 2004-2009 and was Roundtable facilitator from 2007-2009, and another author participated intensively from $2009-2015$ as a Roundtable member. Participant observation involves both interacting within in a social setting and observing behaviors and practices (Creswell 2003). Because two of us have been active participants, we engaged in participatory sense-making through interactions with Roundtable members during Roundtable general meetings, subteam meetings, and field trips. Participatory sense-making occurs when meanings assigned to a social phenomenon are co-created in a way that is not necessarily attributable to any one individual's perceptions, but are products of interaction among those individuals (De Jaegher and Paolo 2007, Fuchs and De Jaegher 2009).

Interviews were transcribed and coded following qualitative data analysis procedures (Creswell 2003, Strauss and Corbin 2008) using NVivo qualitative data analysis software (version 10, QSR International). Individual interview texts were read sequentially, and text segments were inductively assigned open codes, i.e., simple words or phrases that summarize the theme of the segment. As the text coding accumulated, codes were iteratively modified as texts were compared with one another (Boeije 2002). Once codes were consistently assigned across themes, they were grouped into a coding tree according to their similarity (Thomas 2006, Hutchinson et al. 2010). Each branch of the coding tree represents categories of events or processes that affected the Roundtable's adaptability and correspond to the axial coding phase in Strauss and Corbin (2008). Throughout this iterative, inductive process, we engaged in participatory sense-making amongst ourselves (De Jaegher and Paolo 2007, Fuchs and De Jaegher 2009) to arrive at shared interpretations of the general factors affecting the Roundtable's transition from collaborative direction-setting to implementation. This was accomplished by comparing themes and categories against attributes of adaptive governance found in the literature to identify areas of convergence and conflict (Eisenhardt 1989, Boeije 2002). This selective coding step generated the key events and processes described in the following section.

\section{EXAMINING THE ROUNDTABLE'S TRANSITION FROM DIRECTION-SETTING TO IMPLEMENTATION}

Our grounded theory-based analysis generated key events and processes affecting the Roundtable's transition and adaptability. We organized these into three broad phases: (1) internal and external changes affecting adaptability (2006-2009), (2) national policy change opening new windows for collaborative implementation and adaptive management (2009-2011), and (3) forest restoration concepts meshing with routine bureaucratic practices (2011-2014). Under each phase, we examine events and processes that emerged from the data as being influential in the Roundtable's adaptability and are characteristic of that phase of transition.

Internal and external changes affect adaptability (2006-2009)

Almost immediately following the release of the Living with Fire report in 2006, the Roundtable experienced a set of simultaneous events that affected its transition from direction-setting to implementation. First, a mountain pine beetle (MPB) infestation outside of the Colorado Front Range Ponderosa pine zone in Colorado's high country rapidly expanded from 2004 to 2006, killing most mature lodgepole pine trees across 1 million ha. A new multi-stakeholder collaborative body emerged to address the MPB outbreak, the Colorado Bark Beetle Cooperative (CBBC), and helped raise the awareness of federal, state, and local elected officials who, in turn, called on the Forest Service to take immediate action to address risks and hazards associated with the outbreak, especially those related to wildfire in headwater areas serving domestic water supplies. With already scarce resources, the Roundtable was forced to compete for political attention and financial resources with the CBBC and post-MPB outbreak forest management priorities of the Forest Service.

Additionally, some Roundtable members pushed for implementing treatments in higher elevation Front Range forests to remain relevant and take advantage of the opportunity for increased funding and political attention. However, Roundtable participants generally disagreed on the need for such treatments outside of the Ponderosa pine zone; indeed, several scientists and the environmental groups did not see an ecological imperative to restore these forests. The Roundtable spent nearly two years debating whether the Roundtable should extend forest treatments to the higher elevations. One of the participants interviewed by the facilitator in summer 2009 described the loss of implementation focus and incessant debates as negatively affecting the Roundtable's collective effectiveness: "The Roundtable hasn't figured out what it wants to be when it grows up. We kick the ball around the circle again and again. Our original goal was to understand fuel conditions and needs for treatment. We did that pretty well, but ever since, we've struggled with what the Roundtable should be, how to implement the [2006 recommendations] report."

Second, as the Forest Service implemented projects following the release of the 2006 Roundtable recommendations, several of the Roundtable's environmental participants became frustrated with the lack of opportunities to take part in the design and monitoring of projects. One reason is that projects had already undergone environmental review and approval pursuant to the National Environmental Policy Act (NEPA), limiting or eliminating any opportunity for Roundtable participants to be involved in defining or modifying projects to incorporate restoration principles. Further, many of the "NEPA-ready" projects were not specifically designed around forest restoration principles, but rather to reduce fuel loads through thinning of forest stands solely to reduce crown fire spread rather than to modify forest stand structures according to historical ecological reference conditions. Modifying projects would require entirely new NEPA reviews and analyses, an artifact of the Forest Service's legal and administrative requirements, and something the Forest Service and many stakeholders did not want.

Adding to the frustrations was that the effectiveness of forest treatments was not being monitored. Such monitoring is central to adaptive collaborative governance (Lee 1993, Boyle et al. 2001, Gerlak and Heikkila 2006, Fernandez-Gimenez et al. 2008, Tschakert and Dietrich 2010), not only as a way to introduce changes in management actions based on evidence, but to sustain social capital with the collaborative group. As one environmental 
interest group representative on the Roundtable noted during the autumn 2008 interview process: "We're taking a big risk participating in the Roundtable and promoting active forest management in the face of a lot of skepticism from our peers. We have to show that the actions we're pressing for are producing the ecological benefits we're assuming. But then Roundtable members accuse us of not trusting the Forest Service. Well, our whole mantra is: trust, but verify. Are all of these treatments really meeting our restoration goals? We don't have any information that tells us either way."

The information that was reported back to the Roundtable by the Forest Service was about treatment locations and aggregate numbers of acres treated, but not the effect of treatments on restoring ecological processes. This was due in part to the lack of specificity in the science report for how to translate fuels reduction and forest restoration principles into the design of specific treatments. But it also exhibited a structural incentive within the Forest Service to report aggregate "acres treated" without speaking to the effectiveness of those treatments (Dale and Gerlak 2006). The lack of feedback on projects resulted in a degree of distrust among environmental stakeholders and a belief that the existing data were insufficient and unreliable. As a result, several of the environmental participants became disenchanted and began withdrawing from the Roundtable.

Finally, during the course of 2008, several key participants from environmental organizations departed as a result of dissatisfaction with Roundtable progress or either to pursue other career goals or transition into different roles in their home organizations. Additionally, the lead Roundtable scientist retired, and funding for the Roundtable facilitator ended. Facilitation duties fell to a Roundtable staff person for the remainder of 2008 through 2009. The departure of these individuals constituted a loss of leadership, knowledge, commitment, and trust relationships. The Roundtable kept meeting every three months, but primarily for members to share information about each other's activities and not to engage in any coordinated, collective action. Taken together, these three events affected the adaptability of the Roundtable and exposed the inability of the Roundtable to respond to new crises, stakeholder conflicts, and personnel changes.

\section{National policy change opens new windows for collaborative implementation and adaptive management (2009-2011)}

A new opportunity for collaborative implementation opened in 2009, when the Federal Landscape Restoration Act established the Collaborative Forest Landscape Restoration (CFLR) program. The CFLR program is a competitive funding mechanism administered by the Forest Service to deliver money to implement collaboratively defined restoration strategies on national forest lands (Schultz et al. 2012). Eligible projects must define restoration actions on at least 21,000 ha of national forest lands over 10 years, be based on sound science, conserve old-growth forests, provide local employment and economic use of forest restoration wood products, and possess a multi-party monitoring strategy to ensure that restoration goals are being met. The CFLR program implies that restoration goals have already been developed and are ready for implementation.

The Front Range CFLR project was among the first round of projects selected in 2010 and received > US\$1 million for fiscal year 2010. For fiscal years 2011 and 2012, the Front Range CFLR received US\$3.5 million and US\$2.9 million, respectively. In addition to receiving funds dedicated to implementation, the CFLR program requirements for multi-party monitoring of restoration projects provided Roundtable participants the opportunity to define specific forest restoration indicators and measures to guide implementation. Between autumn 2010 and spring 2011, Roundtable participants met monthly to craft a monitoring strategy; a final draft was published June 2011 and included ecological and socioeconomic objectives and indicators. However, the group realized there were still substantial disagreements and uncertainties over specifics indicators and measures of forest restoration. These included how to describe and quantify the patterns of forest structure that were likely produced under natural fire regimes in Ponderosa pine forest structure ecosystems. This lack of consensus about what constitutes forest restoration and wildfire risk reduction across the Colorado Front Range exposed a fundamental issue for the Roundtable, as articulated by a long-time Roundtable member: "When we started developing the CFLR monitoring plan, it didn't take us long to realize that we not only didn't agree on metrics and methods for measuring forest restoration, we didn't even agree on how to define forest restoration! We've been backpeddling ever since. Part of the problem is that we don't have the amount of scientific research other areas [of Ponderosa pine forests of the western United States] have, like in northern Arizona or eastern Oregon. We can't apply results from [those places] to here, and so we're sort of doing a lot of best guesses."

Forest restoration concepts are meshed with routine bureaucratic practices (2011-2014)

To overcome gaps in knowledge about forest restoration metrics, a group of scientifically trained research scientists and technical experts from various government and nongovernmental organizations involved in the Roundtable formed the Landscape Restoration Team ("LR Team") and enacted three actions. First, the team took on the task of specifying monitoring measures and methods that could characterize changes in forest structure at different scales. This included the standard Common Stand Exam forest inventory methods used by the Forest Service, but also required the development and application of new spatially explicit techniques to assess changes in forest structure across the landscape (e.g., 20,000 ha area) resulting from forest treatments. Common Stand Exam monitoring reports are published annually by the Colorado Forest Restoration Institute (CFRI) at Colorado State University; reports on the new spatial analysis methods and results are also published by CFRI.

Second, to derive quantitative ranges of historic forest structure patterns and fire regimes as reference conditions upon which specific restoration prescriptions in the Colorado Front Range could be based, several LR Team participants collectively pooled their technical, personnel, and financial resources to develop a Front Range-wide analysis of historic forest structure patterns and fire regimes. CFLR funds were leveraged to support field data collection. Field data collection was completed in summer 2012 and 2013. Data is being analyzed as of this writing, with initial results for some geographic areas submitted for publication. As field data collection proceeded, the LR Team met regularly to develop written reports on desired conditions for forest restoration based on current available research. These reports are 
intended for use as a citation for Forest Service project planning purposes.

Third, a key Forest Service program manager offered to the Roundtable in autumn 2012 the opportunity to provide detailed input into a proposal to implement forest restoration treatments for a 28,000 ha landscape, the Upper Monument Creek project. As the manager stated at the spring 2012 Roundtable meeting: "Nongovernment groups are frustrated with off-the-shelf NEPA projects that made it difficult for forests to adapt to recommendations from the Roundtable. Desired conditions have been debated within the [Landscape Restoration] team, and this will provide an opportunity to look at questions on a more manageable scale and to address big-scale questions that the Roundtable have been facing on a more manageable landscape. The group can look at different treatment scenarios and compare outcomes to desired future conditions through monitoring and adaptive management."

The LR Team seized the opportunity and worked to develop specific treatment designs based on the team's ongoing learning processes. During this process, it became apparent that team members needed to learn about administrative procedures pertaining to forest project preparation, silvicultural prescriptions, contracting, and administration. Several field trips were conducted to learn about how forest restoration principles are translated into detailed prescriptions that the Forest Service specifies for operators. A key outcome of this process was a "design criteria" report produced by the LR Team that could be directly applicable to and used by Forest Service operational staff as they move through their required procedures. One team member noted the importance of this process at the meeting finalizing the design criteria report: "We've been talking a lot in the abstract about forest structure and fire regimes, but until we worked through the [Upper Monument Creek] project design criteria, we just sort of assumed that foresters would just translate these broad ideas into prescriptions and, voila!, the desired conditions would somehow appear on the landscape. It's been really invaluable working with the field foresters to learn about what they need in terms of written design criteria to base their project preparations and contracts."

While the LR Team's efforts advanced understanding of how to translate broad restoration principles into implementation, several issues remain. Currently, data and knowledge produced by team actions and interactions are not housed in a repository accessible and available to the Roundtable, the Forest Service, and other parties external to the Roundtable. There is no common corporate database to which Roundtable members can turn. Nor do structures or processes exist within the LR Team or the Roundtable as a whole through which monitoring results are collectively deliberated and lead to changes in Forest Service management decisions. This lack of an adaptive management structure and process was expressed by a newer Roundtable member during the autumn 2012 interviews: "We're supposed to come up with recommendations, but there isn't a clear process for providing those recommendations or how decisions are made."

As of this writing, Roundtable members have been working on drafting an adaptive management framework to guide the development of feedback loop structures and processes linking goals, management proposals, implementation, monitoring, and evaluation. It remains to be seen whether the framework will be actualized as a process. In the meantime, collaborative implementation appears to be largely facilitated by individual Forest Service staff. It is unclear if and how the collaborative implementation would proceed should these individuals depart.

Furthermore, as the Roundtable has transitioned into implementation, the scope of Roundtable participants engaged in these processes has narrowed to encompass members with scientific training and technical forestry expertise. In analyzing meeting attendance records, we noted that only a small proportion of Roundtable members have been participating. The general Roundtable membership appears to be content to devolve these technical matters to a smaller subset; at the same time, there is a lack of communication between this subset and the larger Roundtable membership. A member interviewed in 2013 summarized this by saying, "[There are] a lot of informal communications related to specific topics, but it's limited to a smaller group of people. I think there is collaboration within those [sub]groups but it would be nice to have more cross pollination. There isn't a whole lot of communication among or between groups."

\section{INTERPRETATION AND DISCUSSION: PROPOSITIONS FOR FUTURE RESEARCH}

We assessed the adaptability of the Front Range Roundtable as it shifted from direction-setting to implementation. We framed our inquiry using adaptive governance attributes as sensitizing concepts, such as social capital, social learning, and flexibility in applying innovative actions, but employed a grounded theory approach to uncover themes and patterns indicating adaptability based on Roundtable members' experiences and perspectives. Using a grounded theory approach that drew on interviews, documents, and participant-observation, our analysis identified major phases that characterized the Roundtable's transition; within each phase, we uncovered key events or processes that affected the Roundtable's adaptability, and used select interview quotes, meeting notes and reports, and observation data to illustrate the effect of a particular event or process. In sum, we discovered that a combination of events and processes internal and external to the Roundtable affected adaptability.

Stepping back and following Gerlak and Heikkila (2011), we see the opportunity to use the Roundtable case study as a basis for generating propositions to guide future research on how CGRs change and adapt over time, especially for CGRs associated with publicly managed ecosystems, where government bureaucracies maintain significant authority and control over decision-making. Few studies trace change and adaptability of CGRs over time (Emerson et al. 2012; Imperial and Koontz, unpublished manuscript: http://people.uncw.edu/imperialm/Instructor/Papers/ APPAM 07 Imperial_Koontz_Final 11 5 07.pdf). Given the expansion of CGRs in publicly managed ecosystems, advancing research in this area is timely and necessary to understand factors affecting collaborative implementation progress or failure.

\section{Propositions for future research from the Roundtable case study} As a starting point, the literature on the adaptive capacity of collaborative governance highlights social learning, social capital, and flexibility for innovative action as key attributes. The Roundtable case study allows us to reflect on and examine the 
relative effect of these attributes over time as the Roundtable shifted away from direction-setting toward implementation. During the Roundtable's direction-setting, the group's organizational structure and processes fostered a high degree of social capital and learning, resulting in a consensus for a set of broad recommendations to guide restoration action. However, engaging in collaborative implementation challenged the Roundtable's adaptability, as it experienced unanticipated internal and external changes. Operating as an external change, the mountain pine beetle infestation in Colorado's lodgepole pine forests forced the Roundtable to compete for resources with another collaborative governance group and respond to a vocal sub-network within the Roundtable to conduct active forest management in high-elevation lodgepole pine forests. Internally, the lack of monitoring results regarding Forest Service restoration projects led to dissatisfaction among environmentalists participating in the Roundtable, who needed to demonstrate to their parent organizations and peers outside the Roundtable that collaboration is effective at producing desired changes toward forest restoration on national forest lands. The departure of key stakeholders further challenged the Roundtable's adaptability. Despite the high degree of social capital and learning during the direction-setting phase, the Roundtable struggled to adapt in response to the combined effect of an external issue, internal dissention, and membership changes.

CGRs can be especially vulnerable to changes in ecological conditions, changes in internal membership and stakeholder dynamics, and competition between external organizations over resources and scrutiny (Wyborn and Bixler 2013). Indeed, every organization faces challenges to re-adjust to internal and external changes and pressures (Weick and Quinn 1999, Burke 2002) through a continuous dynamic of sensing, improvising, and adjusting (Orlikowski 1996). However, even though individuals within an organization may undergo continuous learning and change, this does not automatically translate into changes in organizational structure and strategies (Fiol and Lyles 1985, Weick and Quinn 1999). A CGR faces the added challenge of being an "organization of organizations" (Imperial and Koontz, page 1, unpublished manuscript: http://people.uncw.edu/ imperialm/Instructor/Papers/APPAM 07 Imperial Koontz Final 115 07.pdf) that must constantly demonstrate effectiveness and legitimacy to its parent organizations and to a variety of external stakeholders (Huxham 2000, Emerson et al. 2012, Taylor and Cheng 2012). Stakeholders who assume leadership roles within the CGR can mediate relationships between the CGR and external stakeholders and are critical to adaptive governance (Olsson et al. 2006). Their departure can leave the group without crucial adaptive capacity.

Perhaps more significantly, the Roundtable lacked clear mechanisms through which its learning could be absorbed and acted upon by Forest Service managers. The collaboration and adaptive governance literature speaks generally to the importance of multi-level linkages and learning across institutions and actors, especially organizational leaders (Adger et al. 2005, Cash et al. 2006, Olsson et al. 2006, Pahl-Wost1 2009). However, missing from this literature are propositions or empirical findings that provide insight into the mechanisms through which a collaborative group's adaptations are translated into changes in resource management decision-making and practice. As the Roundtable sought to move from direction-setting to implementation, it was necessary, but not sufficient, to involve solely Forest Service leadership and program administrators in collaborative governance. While these individuals exert authority and influence over field-level staff, operational decisions about specific management actions are left to the discretion of field staff (Sabatier et al. 1995). In the initial phase of collaborative implementation, the Roundtable's social networks and learning had not encompassed these organizational levels of the Forest Service, thereby limiting its ability to implement flexible, innovative actions. In turn, Forest Service operational field staff had little incentive or interest in participating in what they saw as abstract discussions about forest restoration and wildfire risk mitigation.

This leads to our first proposition: Heightened social capital and learning may not be enough for CGRs engaged in public ecosystem management to withstand inevitable forces of change internal and external to the CGR. Our proposition stems from the recognition that CGRs are nested within a dynamic institutional environment in which actors and organizations are competing for resources and policy advantage (Wyborn and Bixler 2013). People come and go, and parent organizations and government bureaucracies must be attentive to multiple interests and incentives within the broader institutional environment. The absence of structures and processes through which CGRs members can sustain their social networks and incorporate their learning, especially those from public resource management bureaucracies, is likely to limit the adaptability and effectiveness of CGRs. Understanding the necessary extent of social capital for collaborative regimes undergoing changes, and examining the relative contributions of leadership and social capital to policy and governance outcomes, are emerging as important research areas, as well as practical environmental governance concerns (Gutiérrez et al. 2011, Huppé and Creech 2012).

The opportunity for closer alignment between the Roundtable and the Forest Service's implementation actions came with the passage of the Federal Landscape Restoration Act in 2009 and the resulting CFLR program. The importance of supportive higherlevel policies and institutional arrangements is a well-defined attribute of adaptive governance, especially in reference to comanagement arrangements, wherein community members or organizations share authority over resource management decision-making and implementation (Armitage 2005, Folke et al. 2005, Lebel et al. 2006, Plummer 2009).

However, the CFLR program did not specify mechanisms by which collaborative goals were to be translated into action. When it came to developing a multi-party monitoring strategy, the Roundtable, via the LR Team, had to revisit how general forest restoration principles translated into specific monitoring measures and methods. The LR Team had to develop new landscape-scale assessment and monitoring approaches to inform and evaluate the effectiveness of forest restoration treatments. While innovative, there has been little consideration about where documentation on these approaches and the resulting data will reside in the long-term to influence ongoing adaptive management and future decision-making, especially as the CFLR project winds down in 2020 and Roundtable members potentially leave the collaborative group for various reasons, as has happened 
in the past. Like many large bureaucracies, the Forest Service has large corporate databases that heavily influence decision-making and accountability. The CFLR program is silent regarding this matter; it assumes that any multi-party monitoring data and information would be inserted into existing Forest Service information systems.

Further, many commentators identify the importance of engaging scientists and technical subject-matter experts in collaborative governance enterprises (Wondolleck and Yaffee 2000, Bentrup 2001, Scarlett 2013); however, there is a risk of focusing governance actions to scientific and technical matters while not attending to the broader social, cultural, and economic values important across stakeholders. This is a potential paradox for CGRs as they move from direction-setting to implementation: the scope of collaboration increasingly narrows around highly technical matters as collaboratively defined goals are translated into implementation actions. The narrowing has the potential to limit the adaptability of the CGR as the broader set of participants grows distant to implementation details and is not part of the social networks and learning associated with technical experts.

This leads to our second proposition: National policy changes may open a window for reorganizing and refocusing CGRs to move from direction-setting to implementation, but may be insufficient to induce flexible implementation of innovative actions. Our reasoning for this proposition is that while the CFLR program had obvious effects on the Roundtable's adaptability, we are cautious to attribute direct causality. The importance of supportive higher-level policies and institutional arrangements is a well-defined attribute of adaptive governance, especially in reference to co-management arrangements, wherein community members or organizations share authority over resource management decision-making and implementation (Armitage 2005, Folke et al. 2005, Lebel et al. 2006, Plummer 2009). However, some research demonstrates the limited effect that top-down, national-level policy mandates have on field-level Forest Service decision-making; field-level forest managers are more likely to craft decisions based on local ecological and social conditions, and normative values and attitudes (Sabatier et al. 1995).

The Roundtable benefited from individual Forest Service fieldlevel staff who possessed a positive value orientation and attitude toward forest restoration and a willingness to engage with the LR Team on implementation details. The roles and effects of individuals on positively affecting adaptive governance of socialecological systems is well established, with an emphasis on institutional entrepreneurs exerting their influence to spur innovation, adaptation, and transformation (Westley et al. 2013). In contrast, the Roundtable's dependence on individual Forest Service staff makes it sensitive to changes in personnel. Indeed, the Forest Service is well known for a cultural practice of moving staff across field units as a component of professional development and to reduce the capture of agency staff to local interests (Kaufman 1960); this is viewed as a barrier to facilitating collaborative progress (Moote and Becker 2003).

Empirical research by Butler (2013) demonstrates that Forest Service engagement in collaborative implementation of CFLR projects is highly variable and dependent on the individual Forest Service managers involved in these projects. In the case of
CALFED, some researchers argue that a lack of state and federal agency leadership, especially in resolving conflicts and finding mutually acceptable solutions, explains some of its implementation failure (Bobker 2009, Hanemann and Dyckman 2009). The importance of individual field-level staff values and attitudes in policy implementation is highlighted in research on so-called "street-level bureaucrats" (Meyers and Vorsanger 2007). Hence, while national policies can stimulate the adaptability of CGRs as they engage in implementation, that adaptability is reliant in part on the availability and participation of institutional entrepreneurs within bureaucracies who are willing to engage in and translate innovative proposals into implementation action.

As the Roundtable continues to adapt its structures and strategies to correspond to Forest Service implementation procedures and practices, it has attempted to put into practice what Pahl-Wostl (2009) identifies as linking learning across multiple levels of decision-making in nested hierarchies. Three important processes are theorized that enable multi-level learning to occur: (1) actors participate across multiple levels, (2) institutional rules produced at one level influence rules across other levels, and (3) knowledge produced at one level influences decision-making across levels (Pahl-Wostl 2009). The Roundtable has clearly exhibited the first process, but continues to work through challenges associated with the latter two. As the Roundtable case study illustrates, the absence of mechanisms through which social networks and learning can be durably linked to implementation decisions compromises the Roundtable's continued adaptability.

Several commentators speak to the importance of boundary spanners and bridging organizations as important mechanisms of adaptive capacity (Folke et al. 2005, Berkes 2009). These entities are present in the Roundtable's collaborative implementation efforts. However, given the history of Roundtable changes in membership and organizational participation, these may not be durable. One set of attributes observed are boundary objects. We refer to boundary objects as structures that occupy the shared space between groups or organizations and facilitate independent actions and interactions among those groups (Mollinga 2010, Star 2010). In particular, boundary objects are "organic infrastructures" that furnish information and work requirements for groups who wish to cooperate (Star 2010:602). Boundary objects can take physical form, can be attached to organizational structures and processes, and are characterized by interpretive flexibility, i.e., two or more individuals can access information or apply tasks within the boundary object and arrive at different conclusions. For example, boundary objects of the Roundtable may include:

1. Knowledge syntheses and goal recommendations sanctioned by stakeholders, reflected in the 2006 recommendation report and corresponding support documents. The report is already used as guidance for Forest Service implementation and was a foundation for the successful CFLR proposal.

2. Implementation guidelines developed through the Roundtable that are sanctioned for use by Forest Service staff and are cited in Forest Service planning and implementation documents. LR Team members are currently drafting a technical report that will provide guidelines to Forest Service managers to assist in identifying landscapes in need of restoration, defining ranges of forest 
Fig. 2. Framework for examining the adaptability of public ecosystem management collaborative governance regimes.

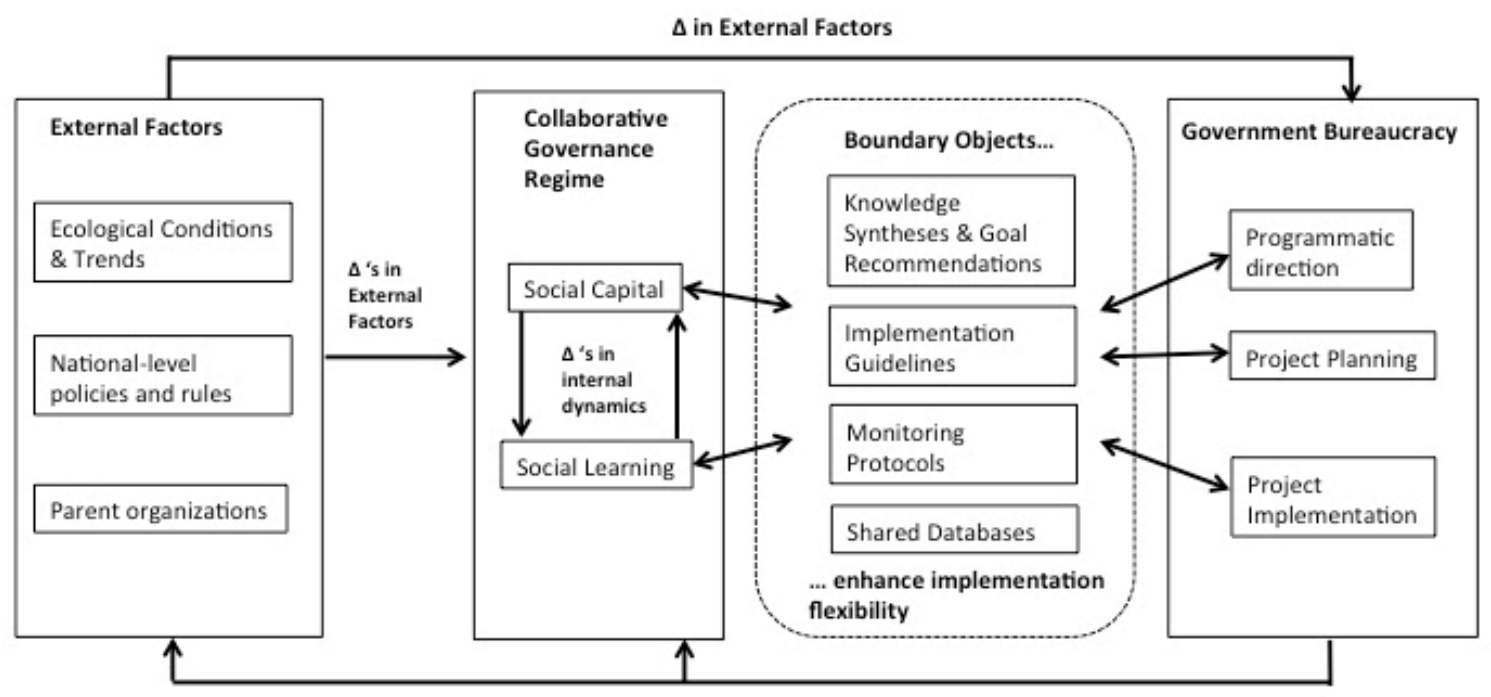

$\Delta$ in Management Outcomes and Effects

management prescriptions at multiple spatial scales, and developing monitoring indicators and measures. The final publication is intended to be used in landscape analysis and project planning.

3. Monitoring and adaptive management protocols that specify tasks, outputs, schedules, and budgetary requirements that are part of the Forest Service annual program of work at the field level. In addition to the 2011 multi-party monitoring plan, several documents have been produced by the LR Team and approved by the Roundtable that describe monitoring protocols to assess the effect of restoration projects on forest stand structure, spatial heterogeneity of stand structures across project areas, and socioeconomic objectives such as employment, wood use, and regional economic activity. At this writing, protocols are being developed to assess restoration treatment effects on wildlife species of interest and understory plants. An adaptive management framework was also developed by the LR Team and approved by the Roundtable that outlines the process by which adaptive management occurs, from defining restoration goals to evaluating monitoring results to changing management actions and restoration goals. In this way, the document encompasses strategies for both single-loop and double-loop learning and change.

4. Databases containing protocols, data, and results that are linked to Forest Service corporate databases and information systems. Some monitoring data collected by the Forest Service and used by the LR Team to evaluate treatment effectiveness are directly compatible with corporate databases. However, data on spatial heterogeneity of forest structures across project areas, socioeconomic outcomes, and understory plants are not directly compatible. Currently, these data are stored on different systems with no access rules.

Even as CGR members come and go, stable boundary objects may provide structural mechanisms through which participants can continue to interact, learn, and translate new knowledge into implementation actions. Hence, it is through boundary objects that social networks and learning produced by CGRs may be absorbed and acted upon by government bureaucracies managing public ecosystems. To sustain adaptability over time, it is necessary for boundary objects to be co-created and co-managed by all CGR members that can endure when boundary spanners and bridging organizations leave or decline in participation.

This leads to our third proposition: CGRs that establish boundary objects tied to the procedures and practices of bureaucracies authorized to implement management actions increase the likelihood of sustaining CGR adaptability and can support more flexible, innovative action. This proposition is informed by an acknowledgement that much of the work of public management, whether it concerns national forests or other areas, occurs through hierarchical public bureaucracies (Agranoff 2006, Kettl 2006, Olsen 2006). Boundary objects, in addition to boundary spanners/ organizations and boundary experiences, have been recognized as critical features to translate knowledge and ideas into durable bureaucratic procedures and practices (Feldman et al. 2006). The literature on collaborative governance has been effective in advancing the notion that public management is moving into a post-bureaucracy era, with networked governance approaches replacing government as the primary way in which public affairs are addressed (Olsen 2006). With regard to National Forest management and other public resource management, CGRs must still confront the existence of government bureaucracies and develop durable structures through which social networks and 
learning can lead to the flexible implementation of innovative actions.

\section{Analytical framework for examining the adaptability of public ecosystem management collaborative governance regimes}

Our three propositions are tied together within an analytical framework (Fig. 2) that characterizes the system in which public ecosystem management CGRs function and adapt. CGRs are shaped by, and change in response to, a set of external factors, most notably ecological conditions and trends, national-level policies and rules, and parent organizations that contribute leadership, members, resources, and legitimacy to the CGR. These same factors can also exert influence over government bureaucracies independent of the CGR. For example, these may include national environmental or economic development policies requiring compliance of all government bureaus. CGR adaptability is also influenced by the development and ongoing evolution of social capital and learning internal to the CGR. The social dynamics arising from social relationships and learning can fall along continua of cooperation or conflict over knowledge and goal recommendations. The extent to which social capital and learning contribute to flexibility in implementation of innovative actions by government bureaucracies is mediated by boundary objects, i.e., material objects and structures that occupy the space between a CGR and the bureaucracy and that provide mechanisms through which CGR learning and ideas can be absorbed and acted upon by the bureaucracy.

Boundary objects may influence decisions and actions in government bureaucracies at different levels, from programmatic direction to project planning and operational implementation. As the bureaucracy implements management actions, outcomes and effects feed back into the CGR and into the larger system of ecosystem conditions, policies and rules, and organizations. Depending on the monitoring systems developed by the CGR, these outcomes and effects cycle through the learning occurring within the CGR, contributing to new knowledge and possibly resulting in new ideas for implementation actions. Management outcomes and effects may also lead to changes in ecological conditions, national-level policies and rules, and parent organizations' expectations and competition for resources.

\section{CONCLUSIONS}

The adaptability and durability of CGRs associated with publicly managed ecosystems over time remains an under-researched topic. An abundance of knowledge about the enabling conditions and structural, process, and behavioral attributes of collaborative environmental governance has been developed (Emerson et al. 2012). However, understanding factors influencing CGR adaptability is critical to advancing scientific knowledge about adaptive environmental governance in general. We especially desire to draw attention to the mechanical workings of government bureaucracies that play such large roles in managing public ecosystems and natural resources. While social capital and learning are well deserved in their recognition as key attributes of adaptive capacity, the ability to implement flexible, innovative actions requires direct confrontation of the structural realities associated with bureaucracies. As CGRs gain more experience with government bureaucracies, and visa-versa, there is a need to build empirically based understandings of their evolution.
To test rigorously the propositions presented here, future research might explore how a larger sample of long-standing CGRs associated with publicly managed ecosystems have succeeded or failed in moving from direction-setting to implementation. The CFLR program and other national-level policies that advance collaborative governance approaches in national forests in the United States provide a readily accessible laboratory to examine the adaptability of CGRs over time. Established measures of social capital and learning can be uniformly applied and classified against implementation actions of bureaucracies over time. The presence, absence, and types of boundary objects is an added dimension of analysis as both outcomes of social capital and learning, and as facilitators of ongoing social capital and learning development vis-a-vis bureaucracies. Do we see implementation actions change over time as measures of social capital and learning increase or decrease? Do boundary objects make a difference in linking social capital and learning to flexible implementation? The expansion and maturation of CGRs associated with publicly managed ecosystems necessitates further examination to advance understanding of their durability and effectiveness.

Responses to this article can be read online at: http://www.ecologyandsociety.org/issues/responses. $\mathrm{php} / 7187$

\section{Acknowledgments:}

We thank Roundtable members for participating in interviews, Tanya Heikkila for providing critical comments and suggestions; and several anonymous reviewers for providing helpful edits and comments. Partial financial support for this research was received from the Agricultural Experiment Station at Colorado State University.

\section{LITERATURE CITED}

Adger, W. N., K. Brown, and E. L. Tompkins. 2005. The political economy of cross-scale networks in resource co-management. Ecology and Society 10(2): 9. [online] URL: http://www. ecologyandsociety.org/vol10/iss2/art9/.

Agranoff, R. 2006. Inside collaborative networks: ten lessons for public managers. Public Administration Review 66(S1):56-65. http://dx.doi.org/10.1111/j.1540-6210.2006.00666.x

Ansell, C., and A. Gash. 2008. Collaborative governance in theory and practice. Journal of Public Administration Research and Theory 18(4):543-571. http://dx.doi.org/10.1093/jopart/mum032

Armitage, D. 2005. Adaptive capacity and community-based natural resource management Environmental Management 35 (6):703-715. http://dx.doi.org/10.1007/s00267-004-0076-Z

Bentrup, G. 2001. Evaluation of a collaborative model: a case study analysis of watershed planning in the Intermountain West. Environmental Management 27(5):739-748. http://dx.doi.org/10.1007/ $\underline{\mathrm{s} 002670010184}$

Berkes, F. 2009. Evolution of co-management: role of knowledge generation, bridging organizations and social learning. Journal of 
Environmental Management 90(5):1692-1702. http://dx.doi. org/10.1016/j.jenvman.2008.12.001

Bernard, T., and J. Young. 1997. The ecology of hope: communities collaborate for sustainability. New Society Publishers, Gabriola Island, Canada.

Bobker, G. 2009. The means do not justify the ends: a comment on CALFED. Environmental Science and Policy 12(6):726-728. http://dx.doi.org/10.1016/j.envsci.2009.06.002

Boeije, H. 2002. A purposeful approach to the constant comparative method in the analysis of qualitative interviews. Quality and Quantity 36(4):391-409. http://dx.doi.org/10.1023/ $\underline{\text { A:1020909529486 }}$

Bonnell, J. E., and T. M. Koontz. 2007. Stumbling forward: the organizational challenges of building and sustaining collaborative watershed management. Society and Natural Resources 20(2):153-167. http://dx.doi.org/10.1080/08941920601052412

Bouwen, R., and T. Taillieu. 2004. Multi-party collaboration as social learning for interdependence: developing relational knowing for sustainable natural resource management. Journal of Community and Applied Social Psychology 14(3):137-153. http://dx.doi.org/10.1002/casp.777

Bowen, G. A. 2006. Grounded theory and sensitizing concepts. International Journal of Qualitative Methods 5(3):12-23. [online] URL: http://ejournals.library.ualberta.ca/index.php/IJQM/article/ download/4367/3497.

Boyle, M., J. Kay, and B. Pond. 2001. Monitoring in support of policy: an adaptive ecosystem management approach. Pages 116-137 in M. K. Tolba, editor. Encyclopedia of global environmental change. Volume 4: responding to global environmental change. Wiley, Chichester, UK.

Bryan, T. A. 2004. Tragedy averted: the promise of collaboration. Society and Natural Resources 17(10):881-896. http://dx.doi. org/10.1080/08941920490505284

Buck, L. E., E. Wollenberg, and D. Edmunds. 2001. Social learning in the collaborative management of community forests: lessons from the field. Pages 1-20 in E. Wollenberg, D. Edmunds, L. Buck, J. Fox, and S. Brodt, editors. Social learning in community forests. Center for International Forestry Research, Bogor, Indonesia.

Burke, W. W. 2002. Organizational change: theory and practice. Sage, Thousand Oaks, California, USA.

Butler, W. H. 2013. Collaboration at arm's length: navigating agency engagement in landscape-scale ecological restoration collaboratives. Journal of Forestry 111(6):395-403. http://dx.doi. org/10.5849/jof.13-027

Cash, D. W., W. N. Adger, F. Berkes, P. Garden, L. Lebel, P. Olsson, L. Pritchard, and O. Young. 2006. Scale and cross-scale dynamics: governance and information in a multilevel world. Ecology and Society 11(2): 8. [online] URL: http://www.ecologyandsociety. org/vol11/iss $2 /$ art8.

Cestero, B. 1999. Beyond the hundredth meeting: a field guide to collaborative conservation on the West's public lands. Sonoran Institute, Bozeman, Montana, USA.
Charmaz, K. 2006. Constructing grounded theory: a practical guide through qualitative analysis. Sage, London, UK.

Cheng, A. S. 2006. Build it and they will come? Mandating collaboration in public lands planning and management. Natural Resources Journal 46(4):841-858. [online] URL: http://lawschool. unm.edu/nrj/volumes/46/4/02 cheng build.pdf.

Cheng, A. S., and V. E. Sturtevant. 2012. A framework for assessing collaborative capacity in community-based public forest management. Environmental Management 49(3):675-689. http:// dx.doi.org/10.1007/s00267-011-9801-6

Corbin, J. M., and A. Strauss. 1990. Grounded theory research: procedures, canons, and evaluative criteria. Qualitative Sociology 13(1):3-21. http://dx.doi.org/10.1007/BF00988593

Creswell, J. W. 2003. Research design: qualitative, quantitative, and mixed-methods approaches. Second edition. Sage, Thousand Oaks, California, USA.

Dale, L., and A. K. Gerlak. 2006. It's all in the numbers: acreage tallies and environmental program evaluation. Environmental Management 39(2):246-260. http://dx.doi.org/10.1007/s00267-005-0332$\underline{\mathrm{x}}$

Daniels, S. E., and G. B. Walker. 1996. Collaborative learning: improving public deliberation in ecosystem-based management. Environmental Impact Assessment Review 16(2):71-102. http://dx. doi.org/10.1016/0195-9255(96)00003-0

De Jaegher, H., and E. Di Paolo. 2007. Participatory sensemaking. Phenomenology and the Cognitive Sciences 6(4):485-507. http://dx.doi.org/10.1007/s11097-007-9076-9

DeLeon, P., and L. DeLeon. 2002. What ever happened to policy implementation? An alternative approach. Journal of Public Administration Research and Theory 12(4):467-492. http://dx.doi. org/10.1093/oxfordjournals.jpart.a003544

Edmunds, D., and E. Wollenberg, editors. 2004. Local forest management: the impacts of devolution policies. Earthscan, London, UK.

Eisenhardt, K. M. 1989. Building theories from case study research. Academy of Management Review 14(4):532-550. http:// dx.doi.org/10.2307/258557

Elbakidze, M., P. K. Angelstam, C. Sandström, and R. Axelsson. 2010. Multi-stakeholder collaboration in Russian and Swedish Model Forest initiatives: adaptive governance toward sustainable forest management? Ecology and Society 15(2): 14. [online] URL: http://www.ecologyandsociety.org/vol15/iss2/art14/.

Emerson, K., and A. K. Gerlak. 2014. Adaptation in collaborative governance regimes. Environmental Management 54(4):768-781. http://dx.doi.org/10.1007/s00267-014-0334-7

Emerson, K., T. Nabatchi, and S. Balogh. 2012. An integrative framework for collaborative governance. Journal of Public Administration Research and Theory 22(1):1-29. http://dx.doi. org/10.1093/jopart/mur011

Feldman, M. S., A. M. Khademian, H. Ingram, and A. S. Schneider. 2006. Ways of knowing and inclusive management practices. Public Administration Review 66(S1):89-99. http://dx. doi.org/10.1111/j.1540-6210.2006.00669.x 
Fernandez-Gimenez, M. E., H. L. Ballard, and V. E. Sturtevant. 2008. Adaptive management and social learning in collaborative and community-based monitoring: a study of five communitybased forestry organizations in the western USA. Ecology and Society 13(2): 4. [online] URL: http://www.ecologyandsociety. org/vol13/iss2/art4/.

Fiol, C. M., and M. A. Lyles. 1985. Organizational learning. Academy of Management Review 10(4):803-813. http://dx.doi. org/10.2307/258048

Folke, C., T. Hahn, P. Olsson, and J. Norberg. 2005. Adaptive governance of social-ecological systems. Annual Review of Environment and Resources 30:441-473. http://dx.doi.org/10.1146/ annurev.energy.30.050504.144511

FRFTP Roundtable. 2006. Living with fire: protecting communities and restoring forests. Findings and recommendations of the Front Range Fuels Treatment Partnership Rountable. Front Range Fuels Treatment Partnership Roundtable, Denver, Colorado, USA. [online] URL: http://www.frontrangeroundtable. org/uploads/Roundtable 2006 recommendations.pdf.

Fuchs, T., and H. De Jaegher. 2009. Enactive intersubjectivity: participatory sense-making and mutual incorporation. Phenomenology and the Cognitive Sciences 8(4):465-486. http:// dx.doi.org/10.1007/s11097-009-9136-4

Gerlak, A. K., and T. Heikkila. 2006. Comparing collaborative mechanisms in large-scale ecosystem governance. Natural Resources Journal 46(3):657-707. [online] URL: http://lawschool. unm.edu/nrj/volumes/46/3/04 gerlak mechanisms.pdf.

Gerlak, A. K., and T. Heikkila. 2011. Building a theory of learning in collaboratives: evidence from the Everglades restoration program. Journal of Public Administration Research and Theory 21(4):619-644. http://dx.doi.org/10.1093/jopart/ $\underline{\text { muq089 }}$

Gerlak, A. K., T. Heikkila, and M. Lubell. 2013. The promise and performance of collaborative governance. Pages 413-434 in M. E. Kraft and S. Kamieniecki, editors. Oxford handbook of $U$. S. environmental policy. Oxford University Press, Oxford, UK. http://dx.doi.org/10.1093/oxfordhb/9780199744671.013.0019.

Glaser, B. G., and A. L. Strauss. 1967. The discovery of grounded theory: strategies for qualitative research. Aldine Publishing, New York, New York, USA.

Gupta, J., C. Termeer, J. Klostermann, S. Meijerink, M. van den Brink, P. Jong, S. Nooteboom, and E. Bergsma. 2010. The adaptive capacity wheel: a method to assess the inherent characteristics of institutions to enable the adaptive capacity of society. Environmental Science and Policy 13(6):459-471. http:// dx.doi.org/10.1016/j.envsci.2010.05.006

Gutiérrez, N. L., R. Hilborn, and O. Defeo. 2011. Leadership, social capital and incentives promote successful fisheries. Nature 470:386-389. http://dx.doi.org/10.1038/nature09689

Hanemann, M., and C. Dyckman. 2009. The San Francisco BayDelta: a failure of decision-making capacity. Environmental Science and Policy 12(6):710-725. http://dx.doi.org/10.1016/j. envsci.2009.07.004
Heikkila, T., and A. K. Gerlak. 2013. Building a conceptual approach to collective learning: lessons for public policy scholars. Policy Studies Journal 41(3):484-512. http://dx.doi.org/10.1111/ psj. 12026

Huppé, G. A., and H. Creech. 2012. Developing social capital in networked governance initiatives: a lock-step approach. International Institute for Sustainable Development, Winnipeg, Canada. [online] URL: http://www.iisd.org/pdf/2012/ developing social capital network gov.pdf.

Hutchinson, A. J., L. H. Johnston, and J. D. Breckon. 2010. Using QSR-NVivo to facilitate the develoment of a grounded theory project: an account of a worked example. International Journal of Social Research Methodology 13(4):283-302. http://dx.doi. org/10.1080/13645570902996301

Huxham, C. 2000. The challenge of collaborative governance. Public Management 2(3):337-357. http://dx.doi.org/10.1080/146$\underline{16670050123260}$

Kallis, G., M. Kiparsky, and R. Norgaard. 2009. Collaborative governance and adaptive management: lessons from California's CALFED water program. Environmental Science and Policy 12 (6):631-643. http://dx.doi.org/10.1016/j.envsci.2009.07.002

Kaufman, H. 1960. The forest ranger: a study in administrative behavior. Johns Hopkins University Press, Baltimore, Maryland, USA.

Keen, M., V. A. Brown, and R. Dyball, editors. 2005. Social learning in environmental management: towards a sustainable future. Earthscan, Abingdon, UK.

Kenney, D. S. 2001. Are community watershed groups effective? Confronting the thorny issue of measuring success. Pages 188-193 in P. Brick, D. Snow, and S. van de Wetering, editors. Across the Great Divide: explorations in collaborative conservation and the American West. Island Press, Washington, D.C., USA.

Kettl, D. F. 2006. Managing boundaries in American administration: the collaboration imperative. Public Administration Review 66(S1):10-19. http://dx.doi.org/10.1111/j.1540-6210.2006.00662. $\underline{\mathrm{X}}$

Koontz, T. M. 2005. We finished the plan, so now what? Impacts of collaborative stakeholder participation on land use policy. Policy Studies Journal 33(3):459-481. http://dx.doi.org/10.1111/ j.1541-0072.2005.00125.X

Koontz, T. M., and C. W. Thomas. 2006. What do we know and need to know about the environmental outcomes of collaborative management? Public Administration Review 66(S1):111-121. http://dx.doi.org/10.1111/j.1540-6210.2006.00671.x

Lebel, L., J. M. Anderies, B. Campbell, C. Folke, S. HatfieldDodds, T. P. Hughes, and J. Wilson. 2006. Governance and the capacity to manage resilience in regional social-ecological systems. Ecology and Society 11(1): 19. [online] URL: http://www. ecologyandsociety.org/vol11/iss1/art19/.

Lee, K. N. 1993. Compass and gyroscope: integrating science and politics for the environment. Island Press, Washington, D.C., USA. 
Maarleveld, M., and C. Dabgbégnon. 1999. Managing natural resources: a social learning perspective. Agriculture and Human Values 16(3):267-280. http://dx.doi.org/10.1023/A:1007559903438

Margerum, R. D. 2007. Overcoming locally based collaboration constraints. Society and Natural Resources 20(2):135-152. http:// dx.doi.org/10.1080/08941920601052404

Margerum, R. D. 2011. Beyond consensus: improving collaborative planning and management. MIT Press, Cambridge, Massachussetts, USA. http://dx.doi.org/10.7551/mitpress/9780262015813.001.0001

Meyers, M. K., and S. Vorsanger. 2007. Street-level bureaucrats and the implementation of public policy. Pages 153-164 in B. G. Peters and J. Pierre, editors. Handbook of public administration. Sage, Thousand Oaks, California, USA. http://dx.doi. org/10.4135/9781848608214.n20

Mills, J., A. Bonner, and K. Francis. 2006. The development of constructivist grounded theory. International Journal of Qualitative Methods 5(1):25-35. [online] URL: http://ejournals. library.ualberta.ca/index.php/IJQM/article/view/4402/3795.

Mollinga, P. P. 2010. Boundary work and the complexity of natural resources management. Crop Science 50(S2):S1-S9. http:// dx.doi.org/10.2135/cropsci2009.10.0570

Montjoy, R. S., and L. J. O’Toole, Jr. 1979. Toward a theory of policy implementation: an organizational perspective. Public Administration Review 39(5):465-476. http://dx.doi.org/10.2307/3109921

Moote, A., and D. Becker, editors. 2003. Exploring barriers to collaborative forestry. Ecological Restoration Institute, Northern Arizona University, Flagstaff, Arizona, USA. [online] URL: http://www.iatp.org/files/Exploring_Barriers to Collaborative_Forestry. pdf.

Munaretto, S., and D. Huitema. 2012. Adaptive comanagement in the Venice lagoon? An analysis of current water and environmental management practices and prospects for change. Ecology and Society 17(2): 19. http://dx.doi.org/10.5751/ ES-04772-170219

Olsen, J. P. 2006. Maybe it is time to rediscover bureaucracy. Journal of Public Administration Research and Theory 16(1):1-24. http://dx.doi.org/10.1093/jopart/mui027

Olsson, P., L. H. Gunderson, S. R. Carpenter, P. Ryan, L. Lebel, C. Folke, and C. S. Holling. 2006. Shooting the rapids: navigating transitions to adaptive governance of social-ecological systems. Ecology and Society 11(1): 18. [online] URL: http://www. ecologyandsociety.org/vol11/iss1/art18/.

Orlikowski, W. J. 1996. Improvising organizational transformation over time: a situated change perspective. Information Systems Research 7(1):63-92. http://dx.doi.org/10.1287/isre.7.1.63

Pahl-Wostl, C. 2009. A conceptual framework for analysing adaptive capacity and multi-level learning processes in resource governance regimes. Global Environmental Change 19(3):354-365. http://dx.doi.org/10.1016/j.gloenvcha.2009.06.001

Pelling, M., and C. High. 2005. Understanding adaptation: What can social capital offer assessments of adaptive capacity? Global Environmental Change 15(4):308-319. http://dx.doi.org/10.1016/ j.gloenvcha.2005.02.001
Plummer, R. 2009. The adaptive co-management process: an initial synthesis of representative models and influential variables. Ecology and Society 14(2): 24. [online] URL: http://www. ecologyandsociety.org/vol14/iss2/art24/.

Reed, M. S., A. C. Evely, G. Cundill, I. Fazey, J. Glass, A. Laing, J. Newig, B. Parrish, C. Prell, C. Raymond, and L. C. Stringer. 2010. What is social learning? Ecology and Society 15(4): r1. [online] URL: http://www.ecologyandsociety.org/vol15/iss4/ resp1/.

Sabatier, P. A., J. Loomis, and C. McCarthy. 1995. Hierarchical controls, professional norms, local constituencies, and budget maximization: an analysis of U.S. Forest Service planning decisions. American Journal of Political Science 39(1):204-242.

Scarlett, L. 2013. Collaborative adaptive management: challenges and opportunities. Ecology and Society 18(3): 26. http://dx.doi. org/10.5751/ES-05762-180326

Schultz, C. A., T. Jedd, and R. D. Beam. 2012. The Collaborative Forest Landscape Restoration Program: a history and overview of the first projects. Journal of Forestry 110(7):381-391. http://dx. doi.org/10.5849/jof.11-082

Scott, J., and P. J. Carrington, editors. 2011. The SAGE handbook of social network analysis. Sage, London, UK.

Selin, S., and D. Chevez. 1995. Developing a collaborative model for environmental planning and management. Environmental Management 19(2):189-195. http://dx.doi.org/10.1007/BF02471990

Singleton, S. 2002. Collaborative environmental planning in the American West: the good, the bad and the ugly. Environmental Politics 11(3):54-75. http://dx.doi.org/10.1080/714000626

Star, S. L. 2010. This is not a boundary object: reflections on the origin of a concept. Science, Technology, and Human Values 35 (5):601-617. http://dx.doi.org/10.1177/0162243910377624

Strauss, A., and J. Corbin. 2008. Basics of qualitative research: techniques and procedures for developing grounded. Third edition. Sage, Thousand Oaks, California, USA.

Sturtevant, V., M. A. Moote, P. Jakes, and A. S. Cheng. 2005. Social science to improve fuels management: a synthesis of research on collaboration. General Technical Report NC-257. U.S. Department of Agriculture, Forest Service, North Central Research Station, St. Paul, Minnesota, USA.

Taylor, K. A., and A. Short. 2009. Integrating scientific knowledge into large-scale restoration programs: the CALFED Bay-Delta Program experience. Environmental Science and Policy 12(6):674-683. http://dx.doi.org/10.1016/j.envsci.2009.07.001

Taylor, P. L., and A. S. Cheng. 2012. Environmental governance as embedded process: managing change in two North American and Central American community-based forestry organizations. Human Organization 71(1):110-122.

Thomas, D. R. 2006. A general inductive approach for analyzing qualitative evaluation data. American Journal of Evaluation 27 (2):237-246. http://dx.doi.org/10.1177/1098214005283748

Thomson, A. M., J. L. Perry, and T. K. Miller. 2009. Conceptualizing and measuring collaboration. Journal of Public Administration Research and Theory 19(1):23-56. http://dx.doi. org/10.1093/jopart/mum036 
Tschakert, P., and K. A. Dietrich. 2010. Anticipatory learning for climate change adaptation and resilience. Ecology and Society 15 (2): 11. [online] URL: http://www.ecologyandsociety.org/vol15/ iss $2 / \operatorname{art} 11 /$.

Van Meter, D. S., and C. E. Van Horn. 1975. The policy implementation process: a conceptual framework. Administration and Society 6(4):445-488. http://dx.doi.org/10.1177/009539977500600404

Wagner, C. L., and M. E. Fernandez-Gimenez. 2009. Effects of community-based collaborative group characteristics on social capital. Environmental Management 44(4):632-645. http://dx.doi. org/10.1007/s00267-009-9347-Z

Walker, D., and F. Myrick. 2006. Grounded theory: an exploration of process and procedure. Qualitative Health Research 16(4):547-559. http://dx.doi.org/10.1177/1049732305285972

Walker, P. A., and P. T. Hurley. 2004. Collaboration derailed: the politics of "community-based" resource management in Nevada County. Society and Natural Resources 17(8):735-751. http://dx. doi.org/10.1080/08941920490480723

Weber, E. P., N. P. Lovrich, and M. Gaffney. 2005. Collaboration, enforcement, and endangered species: a framework for assessing collaborative problem-solving capacity. Society and Natural Resources 18(8):677-698. http://dx.doi.org/10.1080/08941920591005034

Weeks, D., and S. Whimster. 1985. Contexted decision making: a socio-organizational perspective. Pages 167-188 in G. Wright, editor. Behavioral decision making. Plenum Press, New York, New York, USA.

Weick, K. E., and R. E. Quinn. 1999. Organizational change and development. Annual Review of Psychology 50:361-386. http://dx. doi.org/10.1146/annurev.psych.50.1.361

Western, D., R. M. Wright, and S. C. Strum, editors. 1994. Natural connections: perspectives in community-based conservation. Island Press, Washington, D.C., USA.

Westley, F. R., O. Tjornbo, L. Schultz, P. Olsson, C. Folke, B. Crona, and Ö. Bodin. 2013. A theory of transformative agency in linked social-ecological systems. Ecology and Society 18(3): 27. http://dx.doi.org/10.5751/ES-05072-180327

White, A., and A. Martin. 2002. Who owns the world's forests? Forest tenure and public forests in transition. Forest Trends and Center for International Environmental Law, Washington, D.C., USA. [online] URL: http://www.forest-trends.org/documents/ index.php?pubID=159.

Wondolleck, J. M., and S. L. Yaffee. 2000. Making collaboration work: lessons from innovation in natural resource management. Island Press, Washington, D.C., USA.

Wyborn, C., and R. P. Bixler. 2013. Collaboration and nested environmental governance: scale dependency, scale framing, and cross-scale interactions in collaborative conservation. Journal of Environmental Management 123:58-67. http://dx.doi.org/10.1016/ j.jenvman.2013.03.014 